\title{
In Vitro Digestibility of South Texas Range Plants Using Inoculum from Four Ruminant Species
}

\author{
LYTLE H. BLANKENSHIP, LARRY W. VARNER, AND GREGORY W. LYNCH
}

\begin{abstract}
Differences in the in vitro digestible dry matter (DDM) of 26 native forage species in south Texas were determined using rumen inoculum from white-tailed deer, sheep, goat, and steer. The mean DDM of all forages was significantly different for each animal species $(P<.05)$. Deer was the most efficient overall digestor of forbs, shrubs, and prickly pear. Of the grasses sampled, the goat was the most efficient digestor with the steer second. In overall efficiency of digestion of all forages tested, the deer was highest with $52.5 \%$, goat with $49.2 \%$, sheep with $47.5 \%$, and steer with 46.6\%. These data indicate that caution should be exercised when using inoculum from one ruminant species to estimate DDM for another species. Certain plant species were determined to meet the TDN requirements for maintenance levels of the four ruminants.
\end{abstract}

Proper management of south Texas rangeland for various ruminant species requires knowledge of the available food supply for the animals being produced. Forage production and quality relative to the animals requirements are necessary to determine stocking rate and combinations of animals grazed.

The production of quality animals requires availability of a high quality diet. Plants should not only be palatable but also nutritious. The relative importance of these plants in the rangeland vegetation complex will depend on the animal species or combination of species being managed since forage plants may vary in their digestibility when consumed by different animal species. Therefore, our objective in this study has been to determine the in vitro dry matter digestibility of many of these plants in evaluating their nutritional importance.

It is important to consider the nutritional requirements of whitetailed deer since (1) deer is one of the most numerous ruminants on the Rio Grande Plain, (2) economic returns from deer rival or exceed at times those from cattle, and (3) the production of quality animals requires the availability of a quality diet. Often the wild ruminant is "taken for granted" in that range management practices do not provide much consideration for its needs. Knowledge of the nutritional requirements of white-tailed deer, and which plants are capable of providing adequate levels, should influence range management practices, particularly brush clearing operations.

\section{Methods}

The in vitro digestible dry matter (DDM) of native forage species of the Rio Grande Plain of Texas was calculated using rumen inoculum from white-tailed deer (Odocoileus virginianus), Rambouillet sheep, Spanish goat, and Hereford steer.

Inoculum from the domestic species was obtained from one rumen cannulated animal of each species. These animals were all fed a commercial deer feed pellet (17\% crude protein, $8 \%$ crude fiber, $2 \%$ ether extract). Deer rumen inoculum was collected from freshly killed white-tailed deer. These deer were killed when

\footnotetext{
Authors were professor, assistant professor and graduate research assistant, Texas Agricultural Experiment Station, Texas A\&M University, Uvalde, Texas 78801 . Currently Blankenship and Varner (now associate professor) are at Uvalde and Lynch is a wild life biologist with USDA, Forest Service, P.O. Box 338, Afton, Wyo. 83110.

The authors wish to thank Thomas J. Fillinger, Sharon Heineman, and David Moore for their assistance in collecting and analyzing samples. The project was financed primarily by the Caesar Kleberg Research Program in Wildlife Ecology and TAES Projects H 1984 and $\mathrm{H} 6044$.
}

needed. Rumen fluid was strained through cheesecloth into a prewarmed $\left(40^{\circ} \mathrm{C}\right)$ thermos and used within an hour of collection. A standard forage, Engelmann-daisy (Engelmannia pinnatifida Gray), of known in vivo digestibility by cattle, sheep, goats, and deer was included in each in vitro trial. Analytical procedures used were those of Tilley and Terry (1963) with modifications of Newman (1972).

Plants utilized in the study included 13 shrubs, 8 forbs, 4 grasses, and 1 cactus (Table 1) collected from 2 pastures on the Chaparral Wildlife Management Area in Dimmit and LaSalle counties of south Texas. Samples of the plants were taken during all 4 seasons. Such samples usually included about $1 / 2$ to 2 inches of the current plant growth. At least 10 plants of each species were sampled at rand om from each site except for cactus which was sparsely represented. Only current annual growth was sampled. These samples were oven-dried at $60^{\circ} \mathrm{C}$ and ground in a Wiley Mill containing a 2-mm screen.

Statistical analysis of the data was by analysis of variance and Duncan's multiple range test (Little and Hills 1975).

\section{Results}

The mean DDM of all forages was significantly different for each animal species $(P<.05)$ (Fig. 1). Deer was highest with $52.5 \%$, goat $49.2 \%$, sheep $47.5 \%$, and steer $46.6 \%$. These results might be expected when normal diets of the animals are considered. Rumen microorganisms of deer probably were more adapted for digesting most of the forage species sampled. All deer inoculum was obtained from free-ranging animals on native vegetation. The

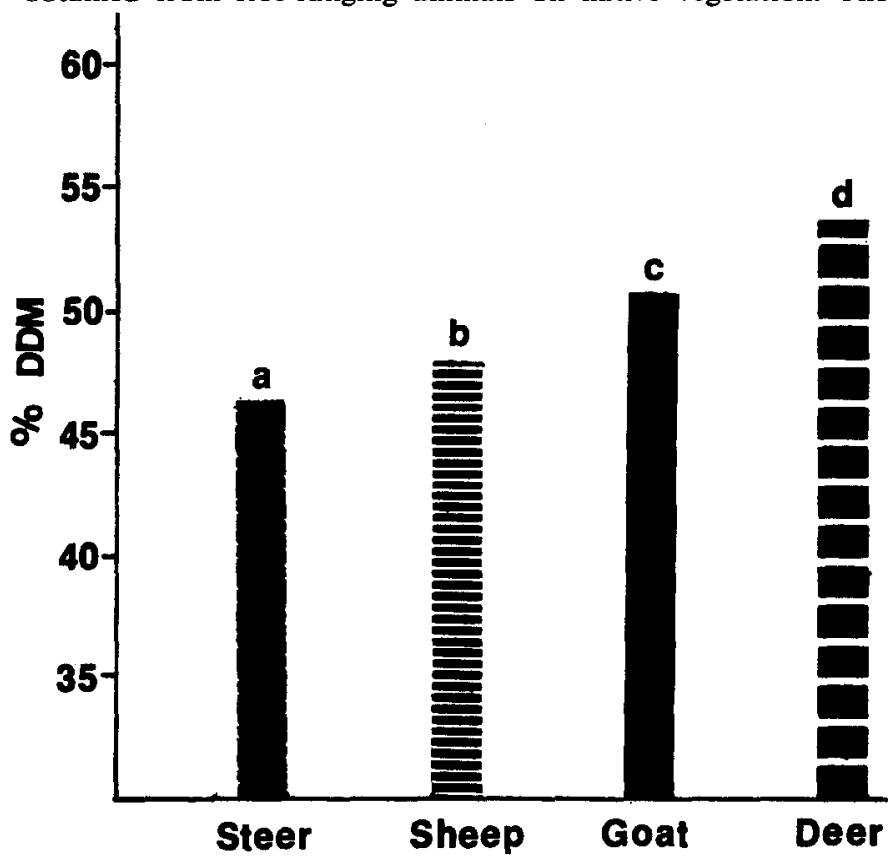

Fig. 1. Percent mean dry-matter digestibility of all forage species for all seasons in 1975 and 1976 as determined with rumen inoculum from the four classes of test animals. Bars topped by the same letter are not significantly different $(\mathrm{P}<.01)$ 
Table 1. Mean DDM of south Texas range plants using inoculum from four animal species.

\begin{tabular}{|c|c|c|c|c|}
\hline \multirow[b]{2}{*}{ Forage species } & \multicolumn{4}{|c|}{$\% \mathrm{DDM}$} \\
\hline & Steer & Sheep & Goat & Deer \\
\hline $\begin{array}{l}\text { Shrubs } \\
\text { Acacia berlandieri (Guajillo) } \\
\text { A. rigidula (Blackbrush) } \\
\text { A. tortuosa (Twisted acacia) } \\
\text { A. wrightii (Wright acacia) } \\
\text { Bumelia celastrina (Coma) } \\
\text { Celtis pallida (Granjeno) } \\
\text { Condalia obovata (Brazil) } \\
\text { C. obtusifolia (Lotebush) } \\
\text { Ephedra antisyphlitica (Vine ephedra) } \\
\text { Eysenhardtia texana (Kidneywood) } \\
\text { Porlieria angustifolia (Guayacan) } \\
\text { Schaefferia cuneifolia (Desert yaupon) } \\
\text { Zanthoxylum fagara (Lime pricklyash) } \\
\text { Mean }\end{array}$ & $\begin{array}{l}28.7 \mathrm{a} \\
20.7 \mathrm{a} \\
26.4 \mathrm{a} \\
37.3 \mathrm{ab} \\
36.9 \mathrm{a} \\
67.0 \mathrm{a} \\
33.8 \mathrm{a} \\
35.0 \mathrm{a} \\
47.0 \mathrm{a} \\
49.5 \mathrm{ab} \\
43.7 \mathrm{a} \\
49.6 \mathrm{a} \\
56.9 \mathrm{a} \\
41.0\end{array}$ & $\begin{array}{l}32.9 \mathrm{ab} \\
20.8 \mathrm{a} \\
30.2 \mathrm{a} \\
39.7 \mathrm{ab} \\
34.9 \mathrm{a} \\
60.7 \mathrm{~b} \\
42.0 \mathrm{~b} \\
27.0 \mathrm{~b} \\
46.8 \mathrm{a} \\
46.5 \mathrm{a} \\
39.8 \mathrm{a} \\
43.3 \mathrm{~b} \\
58.3 \mathrm{a} \\
41.2\end{array}$ & $\begin{array}{l}29.2 \mathrm{ab} \\
28.8 \mathrm{a} \\
27.1 \mathrm{a} \\
36.3 \mathrm{a} \\
35.0 \mathrm{a} \\
67.5 \mathrm{a} \\
44.5 \mathrm{~b} \\
31.8 \mathrm{a} \\
54.9 \mathrm{~b} \\
50.0 \mathrm{ab} \\
39.9 \mathrm{a} \\
49.9 \mathrm{a} \\
54.0 \mathrm{~b} \\
42.2\end{array}$ & $\begin{array}{l}34.4 \mathrm{~b} \\
28.5 \mathrm{a} \\
29.3 \mathrm{a} \\
42.5 \mathrm{~b} \\
48.8 \mathrm{~b} \\
67.4 \mathrm{a} \\
46.4 \mathrm{~b} \\
40.5 \mathrm{c} \\
55.5 \mathrm{~b} \\
51.2 \mathrm{~b} \\
52.8 \mathrm{~b} \\
53.2 \mathrm{a} \\
55.7 \mathrm{ab} \\
46.6\end{array}$ \\
\hline $\begin{array}{l}\text { Forbs } \\
\text { Ambrosia psilostachya (Western ragweed) } \\
\text { Aphanostephus ramossissimus (Plains dozedaisy) } \\
\text { Commelina erecta (Erect dayflower) } \\
\text { Coreopsis nuecensis (Crown coreopsis) } \\
\text { Gaillardia pulchella (Indian blanket) } \\
\text { Hermannia texana (Texas hermannia) } \\
\text { Parthenium hysterophorus (Ragweed parthenium) } \\
\text { Physalis viscosa (Beach groundcherry) } \\
\text { Mean }\end{array}$ & $\begin{array}{l}52.7 \mathrm{a} \\
49.9 \mathrm{a} \\
62.6 \mathrm{a} \\
54.0 \mathrm{a} \\
62.1 \mathrm{a} \\
47.9 \mathrm{a} \\
46.9 \mathrm{a} \\
62.0 \mathrm{a} \\
54.8\end{array}$ & $\begin{array}{l}55.2 \mathrm{a} \\
52.4 \mathrm{a} \\
65.1 \mathrm{ab} \\
55.0 \mathrm{a} \\
62.0 \mathrm{a} \\
55.0 \mathrm{~b} \\
47.2 \mathrm{a} \\
59.2 \mathrm{a} \\
56.4\end{array}$ & $\begin{array}{l}69.0 \mathrm{~b} \\
50.4 \mathrm{a} \\
68.4 \mathrm{~b} \\
62.2 \mathrm{~b} \\
66.6 \mathrm{a} \\
46.9 \mathrm{a} \\
43.5 \mathrm{a} \\
74.2 \mathrm{~b} \\
60.2\end{array}$ & $\begin{array}{l}62.2 \mathrm{c} \\
54.4 \mathrm{a} \\
69.0 \mathrm{~b} \\
62.7 \mathrm{~b} \\
66.2 \mathrm{a} \\
61.7 \mathrm{c} \\
56.3 \mathrm{~b} \\
70.0 \mathrm{c} \\
62.2\end{array}$ \\
\hline $\begin{array}{l}\text { Grass } \\
\text { Cenchrus incertus (Coast sandbur) } \\
\text { Chloris cucullata (Hooded windmillgrass) } \\
\text { Panicum hallii (Hall's panicum) } \\
\text { Setaria macrostachya (Plains bristlegrass) } \\
\text { Mean }\end{array}$ & $\begin{array}{l}49.4 \mathrm{a} \\
48.0 \mathrm{a} \\
49.6 \mathrm{a} \\
36.1 \mathrm{a} \\
45.8\end{array}$ & $\begin{array}{l}41.8 \mathrm{~b} \\
45.9 \mathrm{ab} \\
45.7 \mathrm{~b} \\
38.6 \mathrm{ab} \\
43.0\end{array}$ & $\begin{array}{l}48.9 \mathrm{a} \\
48.6 \mathrm{a} \\
52.8 \mathrm{a} \\
43.8 \mathrm{~b} \\
48.5\end{array}$ & $\begin{array}{l}49.1 \mathrm{a} \\
40.3 \mathrm{~b} \\
49.3 \mathrm{a} \\
41.4 \mathrm{ab} \\
45.0\end{array}$ \\
\hline $\begin{array}{l}\text { Cactus } \\
\text { Opuntia lindheimeri (Texas pricklypear) } \\
\quad \text { Mean of all species }\end{array}$ & $\begin{array}{l}61.5 \mathrm{ab} \\
46.6 \mathrm{a}\end{array}$ & $\begin{array}{l}65.0 \mathrm{a} \\
47.5 \mathrm{~b}\end{array}$ & $\begin{array}{l}56.7 \mathrm{~b} \\
49.2 \mathrm{c}\end{array}$ & $\begin{array}{l}81.1 \mathrm{c} \\
52.5 \mathrm{~d}\end{array}$ \\
\hline
\end{tabular}

inoculum of domestic livestock was obtained from animals fed a commercial diet prepared locally.

Deer were either first or second in efficiency of digestion among all 8 species of forbs sampled (Table 1). Of the domestic species, goat was the next most efficient digestor of forbs with the sheep and steer following in that order. Using western ragweed (Ambrosia psilostachya) as an example, deer had the highest \% DDM for this species in winter while goat was highest during all other seasons (Fig. 2). The ranking shown for sheep and cattle with this species held true generally for all forbs.

For the grasses sampled, the goat was the most efficient digestor for three species. Seasonally, the goat digested such plants as hooded windmill grass (Chloris cucullata) best in spring and winter. The steer was usually the second most efficient digestor of grasses with deer being next and sheep the least efficient.

DDM for 9 of 13 shrub species was highest when using deer inoculum. Goats, sheep, and steer followed in that order. The steer never had the highest DDM for any of the shrub species. All species had a high percent DDM for granjeno (Celtis pallida). Overall, the deer and goat were better digestors of shrubs than either the sheep or steer.

Texas pricklypear (Opuntia lindheimeri) was utilized by deer with an $81 \%$ DDM, much higher than sheep (65\%), steer $(62 \%)$, and goat $(57 \%)$

The animals retained their relative efficiency of digestion in the seasonal breakdown (Fig. 3). Each animal species digested plants with the same efficiency during the winter-spring period and the summer-fall period. However, one ruminant was not always as efficient a digestor as another during these periods. The steer and sheep had low DDM ratings in all seasons, whereas, the deer was high in all seasons. The goat was always second.

\section{Discussion}

The in vitro DDM obtained are felt to be a close approximation of in vivo values (Palmer and Cowan 1980). Rittenhouse et al. (1971) have shown that DDM is highly correlated with digestible energy (DE); therefore, DDM values can for all practical purposes

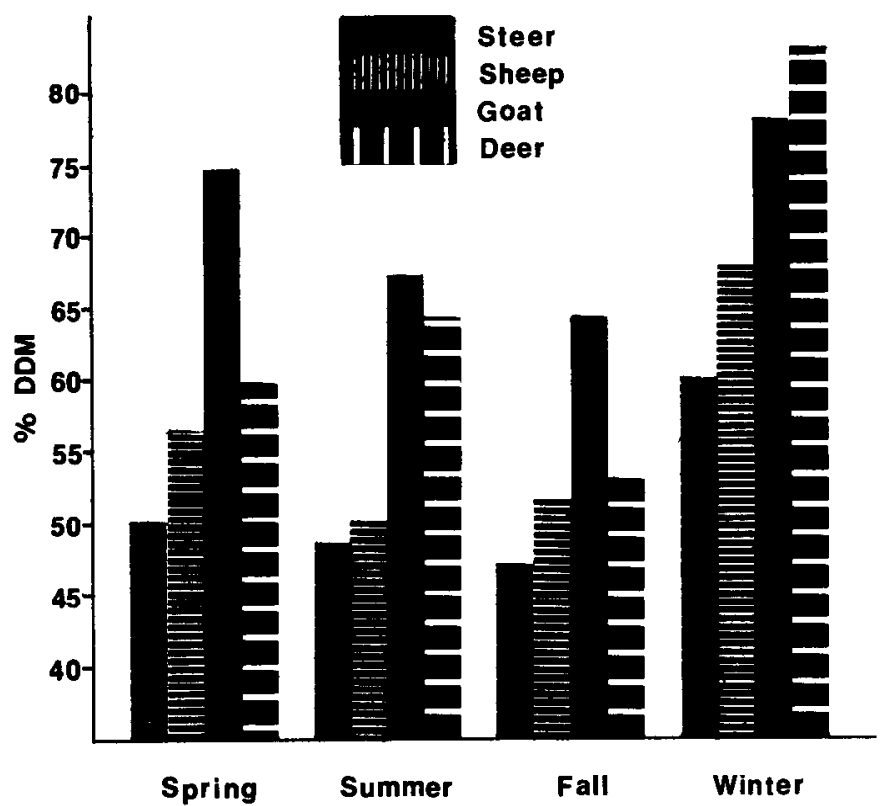

Fig. 2. Seasonal digestible dry matter (DDM) of western ragweed by three species of domestic livestock and white-tailed deer. 


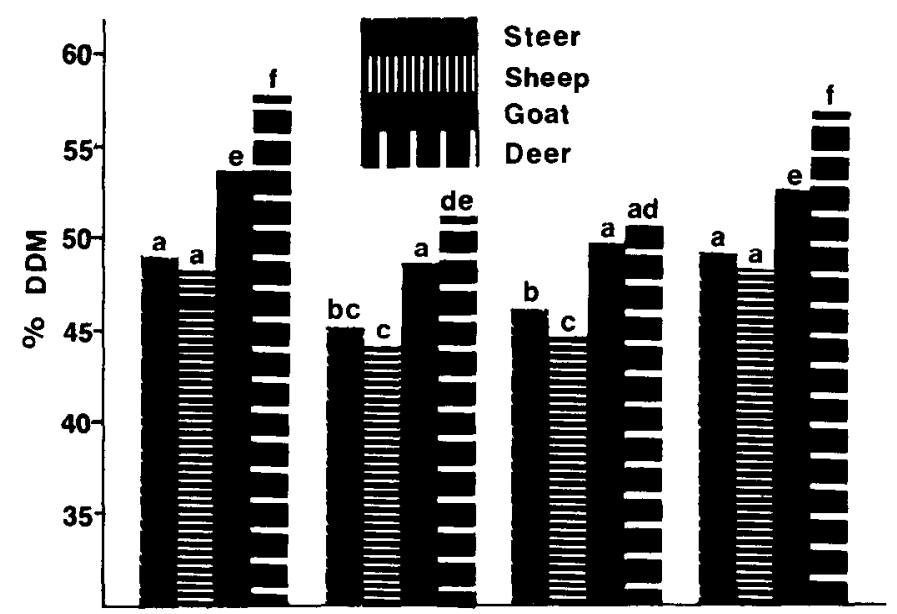

Spring Summer Fall Winter

Fig. 3. Seasonal changes in percent digestible dry matter (DDM) of all forage species as determined with rumen inoculum from the four classes of test animals. Bars topped by the same letter are not significantly different $(\mathbf{P}<.05)$.

be used to predict DE and/or total digestible nutrients (TDN)

A $300-\mathrm{kg}$ calf requires $55 \%$ TDN in the diet for maintenance, but would require $70 \%$ for a daily gain of $0.9 \mathrm{~kg}$. A $500-\mathrm{kg}$ steer, a 300 to $450-\mathrm{kg}$ heifer, and a $500-$ to $1000-\mathrm{kg}$ bull all require $55 \%$ TDN for maintenance (NRC 1976). If cattle utilized these species and if sufficient quantities were consumed, granjeno, lime pricklyash (Zanthoxylum fagara), beach groundcherry (Physalis viscosa).. Indian blanket (Gaillardia pulchella), erect dayflower (Commelina erecta), and pricklypear could be expected to meet the TDN requirement for cattle maintenance levels.

TDN requirements for sheep are the same for all classes except ewes suckling lambs (NRC 1975). A 50- to 80-kg ewe on a maintenance level, as well as a $80-$ to $120-\mathrm{kg}$ ram gaining $150 \mathrm{~g}$ daily, requires $55 \%$ TDN. A 50- to $80-\mathrm{kg}$ ewe suckling either a single lamb or twins requires a $65 \%$ TDN level. Granjeno, western ragweed, beach groundcherry, lime pricklyash, Indian blanket, erect dayflower, and pricklypear provided estimated 55\% TDN for sheep while only erect dayflower and pricklypear met the $65 \%$ requirement.

$\triangle 50 \%$ TDN level is required in the diet of a wether or dry female goat of $45.5 \mathrm{~kg}$ body weight on a maintenance level (Huston et al. 1971). TDN requirement for a lactating doe is $58 \%$ of the diet. Granjeno, vine ephedra (Ephedra antisyphlitica), western ragweed, beach groundcherry, lime pricklyash, Indian blanket, crown coreopsis (Coreopsis nuecensis), ragweed parthenium (Parthenium hysterophorus), Texas hermannia (Hermannia texana), plains dozedaisy (Aphanostephus ramossissimus), erect dayflower, Hall's panicum (Panicum hallii) and pricklypear all provide over $55 \%$ DDM for goats.

Based on studies reported by Blaxter (1962), Silver et al. (1969) and Moen (1973), deer apparently require a level of $52 \%$ to $60 \%$ TDN in the diet depending upon dry matter intake, climatic factors and physiological state. Among the shrub species, desert yaupon (Schaefferia cuneifolia), guayacan (Porlieria angustifolia), granjeno, vine ephedra, and lime pricklyash appear to achieve this energy level. All the forb species evaluated, in addition to pricklypear, also appear to be adequate energy sources. Grasse s appear to be inadequate sources of energy for deer which may account for the relatively small percent of grasses in the diet of deer in south Texas (Arnold 1976, Chamrad and Box 1968).

Since all plants are not adequate during every sea son of the year, a diversity of vegetation on native rangeland is needed to provide adequate nutrient levels for any consuming species by allowing the animal to exhibit dietary selectivity. A nutrient supplement may be necessary during certain periods of stress and drought conditions. The poorly digested mature grasses and some of the mature, woody browse species are poor food sources for small ruminants with high nutritional requirements such as goats, sheep, and deer (Short et al. 1974).

The apparent ability of a deer to select the most nutritious forage available and its mobility make it possible for most individuals of the species to obtain at least a maintenance level of nutrients throughout the year. However, management to alter plant species composition to favor better year round nutrition would promote deer quality. As an example, blackbrush (Acacia rigidula), which is often referred to as a major plant species for white-tailed deer in South Texas, provides cover but little apparent food value. The DDM of $28.5 \%$ for this species was the lowest of all 25 plant species tested. Deer, however, do eat blackbrush and nutritional factors other than its DDM may account for this (Varner et al. 1979).

In contrast, granjeno ranked at the top in overall DDM by all animal species with a mean of $66.5 \%$; for white-tailed deer its DDM was $67.4 \%$. Unless palatability studies show a reason for little use, this plant species appears to be potentially valuable in sustaining white-tailed deer and livestock. The potential digestible energy values of different plant species indicate that certain range sites may be more efficiently utilized by a particular animal species or combination of species. Also, other factors, such as palatability, climatic factors, and physical attributes of the plant must be considered. However, DDM values, if interpreted with diet information and production cycles can provide a basis for making management decisions to achieve the desired composition and production of animal species.

White-tailed deer is an appropriate ruminant for which to manage in much of the South Texas brush country, especially where certain combinations of shrub species occur, such as on shallow ridge sites. Cattle would be preferred in areas managed primarily on grasslands. Goats, being the most verstile, as indicated by DDM data, could be utilized in many areas but would of ten be competitive with deer. The land manager must decide upon which animal species to utilize and then manage his rangeland accordingly.

\section{Literature Cited}

Arnold, L.A. 1976. Seasonal food habits of white-tailed deer (Odocoileus virginianus Bod.) on the Zachry Ranch in South Texas. M.S. Thesis, Texas A\&I Univ., Kingsville. 59 p.

Blaxter, K.L. 1962. The energy metabolism of ruminants. Hutchinson and Co., London. 332 p.

Chamrad, A.D., and T.W. Box. 1968. Food habits of white-tailed deer in South Texas. II Range Manage. 21:158-164.

Gould, F.W. 1975. Texas plants-a checklist and ecological summary. Texas A\&M Univ. Agr. Exp. Sta. Misc. Pub. 585. 121 p.

Huston, J.E., M. Shelton, and W.C. Ellis. 1971. Nutritional requirements of the Angora goat. Texas A\&M Univ., Agr. Exp. Sta. Bull. 1105.16 p.

Little, T.M., and F.J. Hills. 1975. Statistical methods in agricultural research. Univ. of California, Davis. $242 \mathrm{p}$.

Moen, A.N. 1973. Wildlife ecology, an analytical approach. W.H. Freeman and Co., San Francisco. 458 p.

Newman, D.M.R. 1972. A modified procedure for large scale pasture evaluation by digestibility in vitro. J. Australian Inst. Agr. Sci, 46:212213

National Research Council. 1975. Nutrient requirements of sheep. National Academy of Sciences, Washington, D.C. 72 p.

National Research Council. 1976. Nutrient requirements of beef cattle. 5 th ed. National Academy of Sciences, Washingt on, D.C. 55 p.

Palmer, W.L., and R.L. Cowan. 1980. Estimating digestibility of deer foods by an in vitro technique. J. WildI. Manage. 44:469-472.

Rittenhouse, L.R., C.L. Streeter, and D.C. Clanton. 1971. Estimating digestible energy from digestible dry and organic matter in diets of grazing cattle. J. Range Manage. 24:73-75.

Short, H.L., R.M. Blair, and C.A. Segelquist. 1974. Fiber composition and forage digestibility by small ruminants. J. Wildl. Manage. 38:197-209.

Silver, H., N.F. Colovos, J.B. Holter, and H.H. Hayes. 1969. Fasting metabolism of white-tailed deer. J. Wildl. Manage. 33:490-498.

Tilley, J.M.A., and R.A. Terry. 1963. A two-stage technique for the in vitro digestion of forage crops. J. Brit. Grassland Soc. 18:104-11.

Varner, I.W., I.H. Blankenship, and G.W. Lynch. 1979. Seasonal changes in nutritive value of deer food plants in south Texas. Proc. Ann. Conf. S.E. Asso. Fish and Wildlife Agencies 31:99-106. 